\title{
LETTER
}

\section{Frequency of the CHEK2 1100delC mutation among women with early-onset and bilateral breast cancer}

\author{
Dapeng Ding ${ }^{1 *}$, Ying Zhang², Xiaofeng $\mathrm{He}^{3}$, Wei Meng' ${ }^{1}$ Wenli Ma ${ }^{1 *}$ and Wenling Zheng ${ }^{4}$ \\ See related research by Desrichard et al., http://breast-cancer-research.com/content/13/6/R119
}

We read with great interest the recent Breast Cancer Research paper by Desrichard and colleagues [1] reporting the association between CHEK2 mutations and nonBRCA hereditary breast cancer risk. This report summarized the results of different case-control studies to provide an overview of CHEK2 1100delC mutation and susceptibility to early-onset breast cancer (EOBC) and bilateral breast cancer (BBC). We believe there are significant issues to note regarding the authors' study.

To investigate the role of CHEK2 1100delC mutation in BBC susceptibility, Desrichard and colleagues performed a systematic review and pooled analysis based on five studies. Notably, another study that showed contradictory results indicating that the $1100 \mathrm{delC}$ mutation might not be a modifier in BBC [2] was not included in these analyses. Rashid and colleagues [3] have also shared their data, which failed to identify CHEK2 1100delC mutations among cases of BBC. Interestingly, the study by de Jong and colleagues [4] categorized individuals with $\mathrm{BBC}$ as unselected breast cancer cases. However, the BBC cases were included in the group of 192 patients identified with early-onset/familial breast cancer from an Irish study [5]. Hence, ongoing uncertainty exists and, in our opinion, the conclusion reached by Desrichard and colleagues may not be fully supported by the available data.

An additional issue is the association between CHEK2 mutations and $\mathrm{EOBC}$ risk. Using the same search strategy as that of Desrichard and colleagues, we located three relevant case-control studies in PubMed comprising a total of 3,742 EOBC cases and 8,405 controls [6-8], which were not included in the pooled analyses. Furthermore, we have combined all of the studies on European

*Correspondence: ding66zy@gmail.com; genidustry@gmail.com 'Institute of Genetic Engineering, Southern Medical University, Guangzhou, Guangdong, 510515, China

Full list of author information is available at the end of the article populations into a new pooled analysis. By using a fixedeffect model, significant associations were found to be associated with CHEK2 1100delC mutation in patients with EOBC (odds ratio 3.14, 95\% confidence interval 1.86 to 5.28 ).

In conclusion, the association between CHEK2 1100delC mutation and BBC risk may be complex, and further studies will likely be needed to clarify the correlation of BBC and familial breast cancer characteristics. Similarly, further studies on EOBC-specific populations would be helpful for the purpose of better evaluating the association between CHEK2 1100delC mutation and EOBC risk.

\section{Abbreviations}

$B B C$, bilateral breast cancer; $E O B C$, early-onset breast cancer.

\section{Competing interests}

The authors declare that they have no competing interests.

\section{Acknowledgments}

We thank Ms Yanfang Guo (Institute of Bioinformatics, School of Basic Medical Science, Southern Medical University, Guangzhou, China) for scientific editing.

\section{Author details}

'Institute of Genetic Engineering, Southern Medical University, Guangzhou, Guangdong, 510515, China. ${ }^{2}$ College of Pharmacy, Jinan University, Guangzhou, Guangdong, 510632, China. IInformation Section, Peace Hospital of Changzhi Medical College, Changzhi, Shanxi, 046000, China. ${ }^{4}$ Genome

Centre of Southern China, Guangzhou 510830, China.

Published: 20 April 2012

\section{References}

1. Desrichard A, Bidet $Y$, Uhrhammer N, Bignon YJ: CHEK2 contribution to hereditary breast cancer in non-BRCA families. Breast Cancer Res 2011, 13:R119.

2. Dufault MR, Betz B, Wappenschmidt B, Hofmann W, Bandick K, Golla A, Pietschmann A, Nestle-Krämling C, Rhiem K, Hüttner C, von Lindern C, Dall P, Kiechle M, Untch M, Jonat W, Meindl A, Scherneck S, Niederacher D, Schmutzler RK, Arnold N: Limited relevance of the CHEK2 gene in hereditary breast cancer. Int J Cancer 2004, 110:320-325.

3. Rashid MU, Jakubowska A, Justenhoven C, Harth V, Pesch B, Baisch C, Pierl CB, Brüning T, Ko Y, Benner A, Wichmann HE, Brauch H, Hamann U; GENICA Network: German populations with infrequent CHEK2*1100delC and minor associations with early-onset and familial breast cancer. Eur $J$ Cancer 2005, 41:2896-2903. 
4. de Jong MM, Nolte IM, Te Meerman GJ, van der GraafWT, Oosterom E, Bruinenberg M, Steege G, Oosterwijk JC, van der Hout AH, Boezen HM, Schaapveld M, Kleibeuker JH, de Vries EG: No increased susceptibility to breast cancer from combined CHEK2 1100delC genotype and the HLA class III region risk factors. Eur J Cancer 2005, 41:1819-1823.

5. Mclnerney NM, Miller N, Rowan A, Colleran G, Barclay E, Curran C, Kerin MJ, Tomlinson IP, Sawyer E: Evaluation of variants in the CHEK2, BRIP1 and PALB2 genes in an Irish breast cancer cohort. Breast Cancer Res Treat 2010, 121:203-210.

6. Bell DW, Kim SH, Godwin AK, Schiripo TA, Harris PL, Haserlat SM, Wahrer DC, Haiman CA, Daly MB, Niendorf KB, Smith MR, Sgroi DC, Garber JE, Olopade OI, Le Marchand L, Henderson BE, Altshuler D, Haber DA, Freedman ML: Genetic and functional analysis of $\mathrm{CHEK} 2$ (CHK2) variants in multiethnic cohorts. Int J Cancer 2007, 121:2661-2667.

7. Chekmariova EV, Sokolenko AP, Buslov KG, Iyevleva AG, Ulibina YM, Rozanov
ME, Mitiushkina NV, Togo AV, Matsko DE, Voskresenskiy DA, Chagunava OL, Devilee P, Cornelisse C, Semiglazov VF, Imyanitov EN: CHEK2 1100delC mutation is frequent among Russian breast cancer patients. Breast Cancer Res Treat 2006, 100:99-102.

8. Cybulski C, Wokołorczyk D, Huzarski T, Byrski T, Gronwald J, Górski B, Debniak T, Masojć B, Jakubowska A, van de Wetering T, Narod SA, Lubiński J:

A deletion in CHEK2 of 5,395 bp predisposes to breast cancer in Poland. Breast Cancer Res Treat 2007, 102:119-122.

\section{doi:10.1186/bcr3159}

Cite this article as: Ding D, et al.: Frequency of the CHEK2 1100 delC

mutation among women with early-onset and bilateral breast cancer. Breast Cancer Research 2012, 14:401. 